\title{
THE EFFECT OF BACTERIAL CONSTITUENTS ON THE RESIST- ANCE OF MICE TO HETEROLOGOUS INFECTION AND ON THE ACTIVITY OF THEIR RETICULO-ENDOTHELIAL SYSTEM
}

\author{
By DIETHELM BOEHME, M.D., aNd RENE J. DUBOS, Pr.D.
}

(From The Rockefeller Institute for Medical Research)

\author{
(Received for publication, December 3, 1957)
}

Recent studies have revealed that the administration of purified endotoxins derived from Gram-negative bacilli, or of cellular components of mycobacteria, can increase in a lasting manner the resistance of mice to various types of heterologous bacterial infections (1-5).

There is evidence that the activity of endotoxins in this regard is associated with a component which has been designated as "Lipid A" $(6,7)$ and is related to the sequence of hydrophobic and hydrophilic groups in the molecule of this lipide (8). It is also known that certain types of infection modify resistance to heterologous microbial agents, but this aspect of the problem will not be considered here.

Administration of endotoxins has many other physiological effects in mice. It can bring about an increase of phagocytic activity of white blood cells (9), an activation of the properdin system (10), a stimulation of the hypophyseal-adrenal complex (11, 12 ), and profound changes in the so called reticulo-endothelial system (RES) ${ }^{1}(13)$. Other physiological alterations have been recognized in higher animals as well as in man (14-16).

Of special relevance to the present study are the findings which bear on the phagocytic activity of the RES (17-19). In brief, it can be said that the change in phagocytic activity of this system elicited either by infection with Gram-negative bacilli, or by injection of their toxins, is conditioned by the species and age of the animal, by the rate of blood flow through the liver, and by the characteristics and amounts of the infectious agent or of the endotoxin (20). The change in phagocytic activity follows in general a fairly characteristic pattern. There is first a phase of decreased activity, followed by a positive phase which reaches a maximum 3 to 5 days after treatment or infection. Phagocytic activity then progressively decreases, reaching a normal level around the 7th to 9th day. In fatal infections, needless to say, the activity of the RES falls to a subnormal level some time before death.

In animals which have been treated with a protective dose of endotoxin the injection of bacteria elicits a stimulation of the RES more pronounced than that elicited by either infection, or endotoxin alone. In this case again, phagocytic activity does

\footnotetext{
1 The expression RES is used here with full awareness of its ambiguity. In the present study the RES is defined in terms of a particular activity, - namely the uptake of carbon particles.
} 
eventually return to a normal level, but more slowly than in the case of untreated animals.

The present study is an attempt to define more precisely the interrelationships between susceptibility to infection, and phagocytic activity of the RES, as modified by pretreatment with bacterial constituents (salmonella endotoxin and killed BCG cells). Special emphasis has been placed on the reactions observed when the infective dose is administered long after the endotoxin, at a time when the obvious effects of administration of the latter are no longer detectable by ordinary tests.

\section{Materials and Methods}

All infection tests were carried out with a culture of $M y$ cobacterium fortuitum (strain Penso). The origin and characteristics of this strain are described in reference 5. Animals were infected by the intravenous route with $0.05 \mathrm{ml}$. of a 5 to 7 day old culture in tween-albumin medium, diluted to a final volume of $0.2 \mathrm{ml}$. with physiological saline.

The endotoxin used had been derived from a culture of Salmonella abortus equi (6) and is available commercially under the trade name pyrexal. It was prepared by Dr. Otto Westphal (Dr. A. Wander Forschungsinstitut, Freiburg/Baden, Germany), who generously made it available to us. His preparation was listed as AE 1298 S4.

The killed BCG cells were kindly supplied by Dr. Gladys Hobby of Chas. Pfizer \& Co., Inc., Brooklyn. They had been prepared from strain BCG-P by the technique mentioned in an earlier publication (5). One batch of killed cells was washed with acetone, and the other thoroughly extracted with hot acetone by Dr. Russell W. Schaedler of this laboratory.

The animals were male albino mice of the so called Swiss Rockefeller strain. They ranged from 4 to 7 weeks of age and weighed from 19 to $34 \mathrm{gm}$. They were kept in a separate animal room in steel cages with sawdust changed three times weekly. They were fed pellets and water ad lib.

The activity of the RES was tested by a method based on rate of clearance of carbon particles following intravenous injection of India ink (21-23). Under the conditions of this technique and with the proper amounts of India ink, the particles are taken up almost exclusively in the liver and spleen. As the results of the technique are influenced by the size of the particles, it is important to use a stable suspension of homogeneous size (250 angstroms). The material that we used was prepared by Dr. Baruj Benacerraf of New York University Medical School from the commercially available suspension C $111431 \mathrm{a},{ }^{2}$ and was generously supplied to us by him (23). This standardized preparation was devoid of toxicity.

In each experiment groups of approximately 35 mice, treated and infected, were studied in comparison with an equal number of controls. The influence on RES activity exerted by injecting water, endotoxin, killed BCG cells, and the infective dose of $M y c o$. fortuitum, singly or in association, was investigated in separate experiments. In each case the animals were tested on 7 different test days within the 16 days that followed administration of endotoxin or infection. On each test day five treated animals were compared with five untreated controls.

Each mouse received by the intravenous route a dose of $16 \mathrm{mg}$. carbon per $100 \mathrm{gm}$. body weight. After 2, 4, 6, 8, 10, and 15 minutes, $0.025 \mathrm{ml}$. of blood was withdrawn from the retroorbital venous plexus in the nasal angle of the eye. In animals which cleared the ink

\footnotetext{
${ }^{2}$ Günther Wagner, Hanover, Germany.
} 
very rapidly, blood samples were taken $1,3,5,7,9$, and 10 minutes after injection. The blood samples were immediately bemolyzed in $2 \mathrm{ml}$. of $1: 1000$ solution of sodium carbonate $\left(\mathrm{Na}_{2} \mathrm{CO}_{3}\right)$ in distilled water. The amount of carbon present in the sample was then determined electrophotometrically in a Coleman colorimeter set at 675 lambda. From this reading the log of the true concentration of carbon particles was calculated. Once the carbon clearance test had been completed, the animals were killed with chloroform and their livers and spleens weighed.

The following values were determined for each single animal:

1. Body weight.

2. Combined weights of liver and spleen.

3. The quotient $\frac{\text { Body weight }}{\text { (Liver }+ \text { spleen) weight }}$.

4. The clearance value $K$. This factor was determined by plotting the log of the carbon concentration in each blood sample against the time of bleeding. The points thus obtained give an approximately straight line. The slope of this curve is the value $K$, expressed by the equation $=K \frac{(\log \text { conc. } 1)-(\log \text { conc. } 2)}{t_{2}-t_{1}}$ in which $t_{1}$ and $t_{2}$ represent the time in minutes when samples 1 and 2 were withdrawn.

5. The corrected phagocytic index $\alpha$, which is the value corrected for the weight of liver and spleen (21). This factor serves as an index of the activity of the RES in relation to quotient 3 and is described by the equation $\alpha=K \times \frac{\text { Body weight }}{\text { (Liver }+ \text { spleen) weight }}$.

On each test day several treated mice (usually five) were compared with an equal number of untreated controls and the arithmetic means and their standard deviations were calculated for factors $2,3,4$, and 5. Results exceeding twice the standard deviations were considered statistically significant (24). In one experiment, groups of seven mice were compared with seven controls.

\section{RESULTS}

The following experiments were performed to test the protective effect exerted by pretreatment with endotoxin or with killed BCG cells against infection with Myco. fortuitum (3).

In one experiment 96 mice, 5 weeks old, were randomized and divided into four groups of 24 . Within each of these groups, eight animals received $80 \mu \mathrm{g}$. of salmonella endotoxin, eight $20 \mu \mathrm{g}$. of the same material, and eight distilled water. All injections were by the intraperitoneal route in a final volume of $0.4 \mathrm{ml}$. All animals were challenged by infection with $M y c o$. fortuitum, the first group 1 day, the second group 3 days, the third group 1 week, the fourth group 4 weeks after treatment.

In another experiment 32 mice, 5 weeks old, were randomized and divided into four groups of eight. One was treated with $300 \mu \mathrm{g}$. of acetone-washed BCG cells, a second group with $100 \mu \mathrm{g}$. and a third group with $30 \mu \mathrm{g}$., in each case resuspended in $0.3 \mathrm{ml}$. distilled water. The fourth group received water alone. All injections were by the intraperitoneal route. All animals were challenged with $M y c o$. fortuitum 1 week after treatment with killed BCG cells.

The survival times of infected animals in the two protection experiments are presented together in Table $\mathrm{I}$.

The protective effect of killed BCG cells was tested at only one time interval, namely 1 week after treatment. At that time all three doses used proved to be 
effective. With salmonella endotoxin also, no differences could be detected between the protective effects of 20 and $80 \mu \mathrm{g}$. With both doses, protection became evident 24 hours after treatment and was still marked 4 weeks later.

TABLE I

Effect of Intraperitoneal Injection of Salmonella Endotoxin and Acetone-Washed BCG on Susceptibility of Mice to Infection with $M y$ co. fortuitum

\begin{tabular}{|c|c|c|c|c|c|c|c|c|c|c|}
\hline$\underset{\text { (i. }}{\operatorname{Mate}}$ & & $\begin{array}{c}\text { Interval } \\
\text { between } \\
\text { pretreatment } \\
\text { and }\end{array}$ & & & ths at & $\begin{array}{l}\text { dicat } \\
\text { fter i }\end{array}$ & $\begin{array}{l}\text { numb } \\
\text { ction }\end{array}$ & of day & & \\
\hline Pyrexal & 80 & 24 hrs. & $2 \xi$ & - & - & - & - & - & - & - \\
\hline " & 20 & & 5 & 23 & 28 & 28 & - & - & - & - \\
\hline Water & & $"$ & 5 & 5 & 6 & 16 & 16 & 23 & - & - \\
\hline Pyrexal & 80 & 72 hrs. & - & - & - & - & - & - & - & - \\
\hline$"$ & 20 & " & 16 & - & - & 一 & - & - & - & 一 \\
\hline Water & & " & 6 & 21 & 22 & 25 & 30 & 35 & - & 一 \\
\hline Pyrexal & 80 & $1 \mathrm{wk}$. & 20 & 22 & 27 & - & - & 一 & 一 & - \\
\hline$" 6$ & 20 & 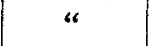 & 3 & 25 & - & - & - & - & - & 一 \\
\hline Water & & “ & 3 & 3 & 3 & 3 & 4 & 4 & 4 & 5 \\
\hline Pyrexal & 80 & 4 wks. & 18 & 22 & 29 & - & - & - & - & 一 \\
\hline " & 20 & “ & 19 & - & - & - & - & - & - & - \\
\hline Water & & “ & 5 & 13 & 13 & 13 & 18 & 21 & - & 一 \\
\hline Killed BCG & 300 & $1 \mathrm{wk}$. & - & - & - & - & - & - & - & - \\
\hline " & 100 & & - & - & - & - & - & - & - & - \\
\hline “ & 30 & “ & - & - & - & - & - & - & - & - \\
\hline Water & & “ & 3 & 4 & 4 & 12 & - & - & - & 一 \\
\hline
\end{tabular}

* Injected intraperitoneally in a final volume of $0.2 \mathrm{ml}$,

$\ddagger 0.05 \mathrm{ml}$. of a 6 day old tween-albumin culture of $M y c o$. fortuitum injected intravenously in final volume of $0.2 \mathrm{ml}$.

8 animals in each group. The sign - indicates that the animal was still living when the experiment was discontinued 4 weeks after infection.

The following experiment was instituted to determine the effect of pretreatment of mice with killed cells of BCG, or with salmonella endotoxin, on the rate at which infected carbon particles were cleared from their blood stream.

Mice 5 weeks old received by the intraperitoneal route either $20 \mu \mathrm{g}$. of salmonella endotoxin or $200 \mu \mathrm{g}$. of acetone-washed killed BCG cells resuspended in $0.3 \mathrm{ml}$. distilled water. At several intervals of time after treatment the ability of these animals, as well as of untreated controls, to clear carbon particles from their blood stream, was tested by the method described above. The results are presented in the left part of Fig. 1. Each point on the curves 
corresponds to the arithmetic mean for five test animals. The standard deviation for the controls is indicated by the broken line.

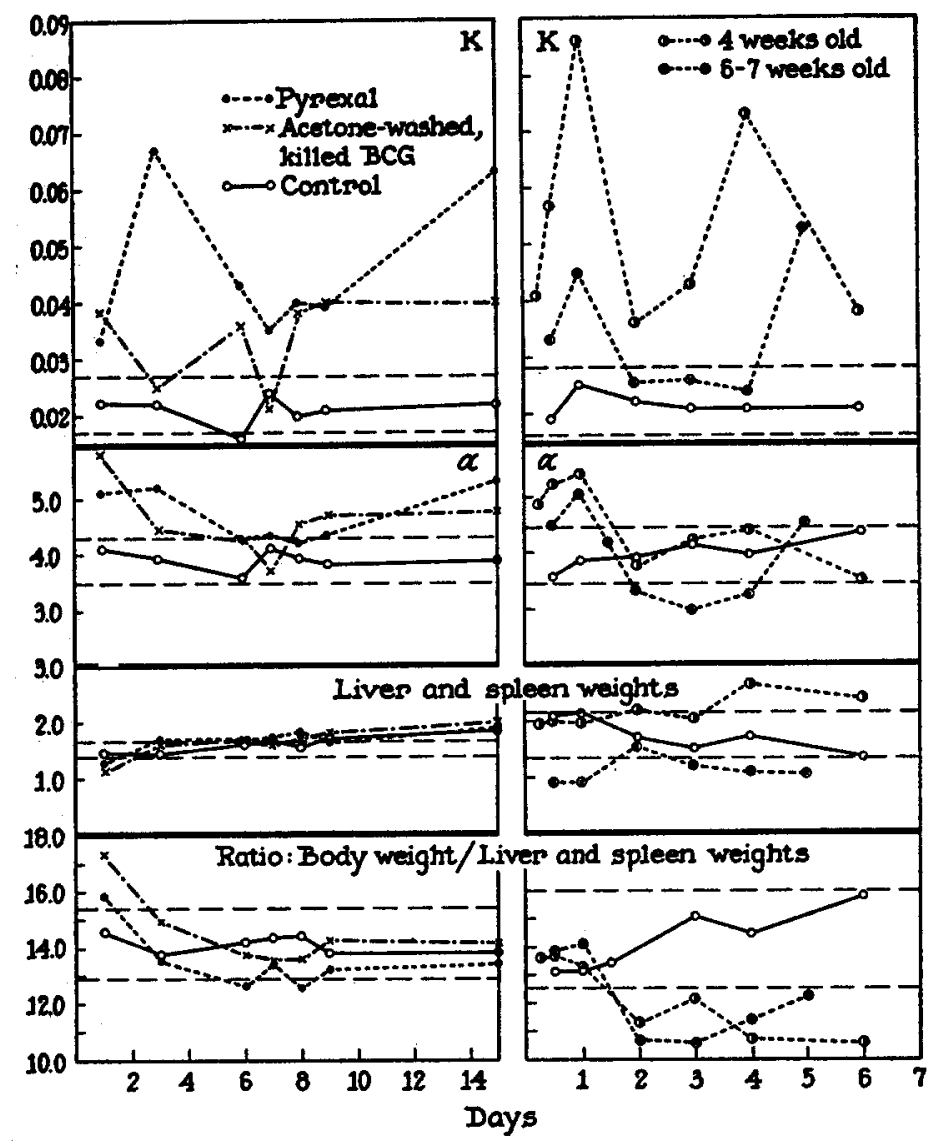

Fic. 1. Comparative effect of treatment with non-living bacillary materials and of infection with $M y c o$. fortuitum on clearance rate of carbon particles. Each point corresponds to the arithmetic means of five animals; the broken line indicates the standard deviation for the untreated controls.

Left: $S$. abortus equi endotoxin (pyrexal) $20 \mu \mathrm{g}$. administered intraperitoneally in a final volume of $0.4 \mathrm{ml}$. of distilled water. Acetone-washed, killed BCG $200 \mu \mathrm{g}$. administered intraperitoneally in a final volume of $0.4 \mathrm{ml}$. of distilled water.

Right: Infective dose: $0.05 \mathrm{ml}$. of a 6 day old tween-albumin culture of $M y c o$. fortuinu, strain Penso, injected intravenously in a final volume of $0.2 \mathrm{ml}$. of distilled water.

The effect of infection with $M y c o$. fortuitum on the clearing power of untreated animals was tested in two separate experiments. The mice used in one experiment were 4 weeks old, in the other 6 to 7 weeks old. They were infected by the intravenous route with $0.05 \mathrm{ml}$. of a 6 day old culture of $M y c o$. fortuitum in tween-albumin medium, diluted to $0.2 \mathrm{ml}$. with dis- 
tilled water. The results of tests for the clearance of carbon particles are presented on the right half of Fig. 1, in a manner similar to that described for the preceding experiment.

As appears from the results presented in Fig. 1 (left), treatment with $20 \mu \mathrm{g}$. of salmonella endotoxin or with $200 \mu \mathrm{g}$. of acetone-washed BCG cells increased markedly the rate at which mice cleared carbon particles from their blood stream. It may be mentioned in passing that injection of $0.3 \mathrm{ml}$. of the water diluent did not exert any detectable effect on the rate of uptake of carbon particles. With both bacterial constituents, the stimulation of phagocytic activity lasted for several days. The $\alpha$ value, corresponding to the phagocytic activity corrected for the weight of liver and spleen of each individual animal at the time of the test, appeared to be maintained somewhat longer in the case of salmonella endotoxin, but the general trend was the same for both products. It is worthy of notice that in the doses employed, neither the endotoxin nor the killed BCG cells caused any detectable increase in the weight of the liver or spleen.

The course of events was different in the case of animals infected with $M y c o$. fortuitum. In the experiment with older mice ( 6 weeks old), both the clearance rate and the phagocytic index $\alpha$ increased during the first 2 days after infection, then again fell back toward normal levels. The higher levels observed at the end of the experiment corresponded to values for a few animals which were still surviving at a time when most of the others had died of the infection. In the experiment with younger mice ( 4 weeks old), a marked increase in the clearance value $K$ and in the phagocytic index $\alpha$ was apparent as early as 16 and 24 hours after infection; moreover both values remained elevated throughout the duration of the experiment (none of the animals had died of the infection by the time the experiment was completed). In contrast with what had been observed in uninfected animals (treated with endotoxin, or with BCG cells), a definite increase in the weight of the liver and of the spleen occurred 2 to 5 days after infection and the increase persisted from then on.

As shown in Table I, the protection exerted by pretreatment with salmonella endotoxin against Myco. fortuitum lasted for several weeks, longer than the other effects of this material so far recorded. It was of interest, therefore, to determine the extent to which infection brought about change of phagocytic activity in animals which had been pretreated with endotoxin or with BCG material at different intervals of time before infection.

\footnotetext{
Mice, 4 weeks old, received by the intraperitoneal route $20 \mu \mathrm{g}$. of salmonella endotoxin in a volume of $0.4 \mathrm{ml}$. of distilled water (Fig. 2). They were then infected by the intravenous route with $0.05 \mathrm{ml}$. of a 6 day old culture of $M y c o$. fortuitum either 12 hours, 3 days, 1 week, 4 weeks, or 8 weeks after treatment. The ability of the infected animals, as well as of the absolute controls, to clear carbon particles from their blood stream was tested by the usual technique. The results are presented in Figs. 2 and 3. Each point on the curves corresponds to the arithmetic mean for five animals; the standard deviation for the controls is indicated by the broken lines.
} 


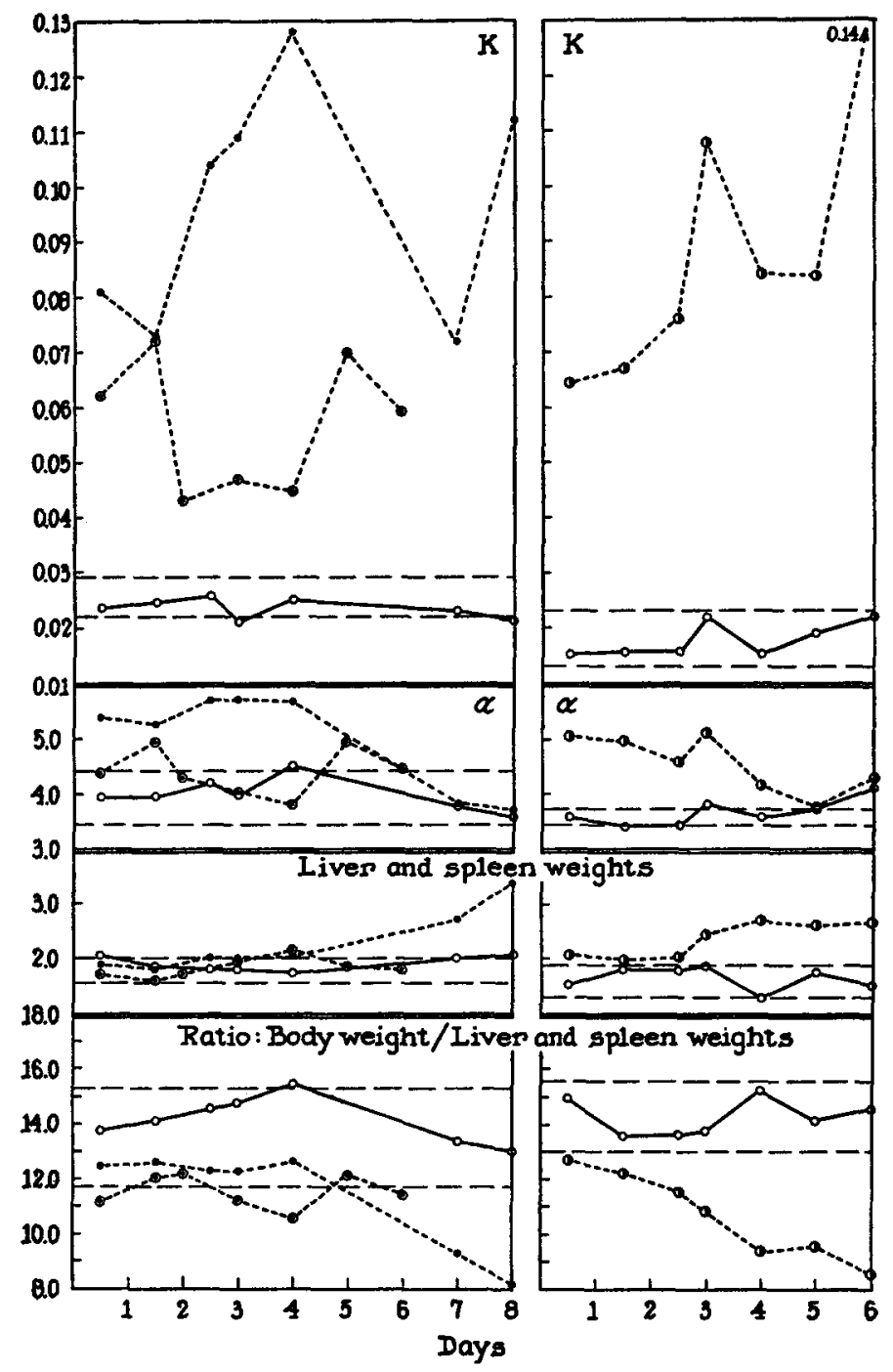

$\rightarrow 12$ hour interval between pretreatment and infection

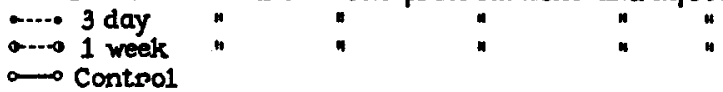

Fic. 2. Short term effect of infection on clearance rate of carbon particles in mice previously treated with pyrexal. Each point corresponds to the arithmetic means of five animals; the broken line indicates the standard deviation of the untreated controls.

Left: One group of animals received $20 \mu \mathrm{g}$. of $S$. abortus equi endotoxin (pyrexal) intraperitoneally in a final volume of $0.4 \mathrm{ml}$. of distilled water and was challenged 12 hours later. The other group received an identical dose of salmonella endotoxin, but was challenged 3 days later.

Right: Treated intraperitoneally with $20 \mu \mathrm{g}$. of $S$. abortus equi endotoxin (pyrexal) in a final volume of $0.4 \mathrm{ml}$. of distilled water 1 week prior to challenge.

All three groups challenged with $0.05 \mathrm{ml}$. of a 6 day old tween-albumin culture of $M y c o$. fortuitum, strain Penso, in a final volume of $0.2 \mathrm{ml}$. of distilled water. 
The results of two separate experiments in which the challenge infection had been administered either 12 hours or 3 days after treatment with endotoxin are presented on the left side of Fig. 2. The right side of Fig. 2 presents the results for the 1 week interval. The results for the 4 week and 8 week intervals are presented respectively on the left side and right side of Fig. 3.

As seen in Fig. 2, administration of the endotoxin 12 hours before infection increased markedly the ability of the animals to clear carbon particles from their blood stream-whether the activity is expressed in terms of clearance value $K$ or of the corrected phagocytic index $\alpha$. The response was even more striking when the endotoxin was administered 3 days or 1 week before infection. In these experiments, the effect became apparent almost immediately (12 hours after infection) and was so large 5 to 6 days later that the $K$ value cannot be properly placed on the graph (Fig. 2). Whereas $K$ remained high throughout the test, the $\alpha$ value returned to a normal level after the 6th day because the weights of the spleen and liver of infected animals had begun to increase the 4th day after infection. None of the infected animals died in the course of the experiment.

The results presented in Fig. 3 illustrate the long term effects of treatment with salmonella endotoxin. Animals infected 4 weeks after treatment responded somewhat more slowly than when the interval had been shorter ( 3 days or 1 week as in Fig. 2). Nevertheless, their response was more rapid than normal, reaching its peak on the 4th day after infection. The phagocytic index $\alpha$ was above normal only on the 4 th day, then decreased as the weights of the spleen and liver increased. Although the response was less pronounced, the clearance value $K$ remained somewhat elevated throughout the course of the experiment in animals infected 8 weeks after treatment with endotoxin. As to their $\alpha$ value, it fell below normal as a result of the marked increase in the weights of spleen and liver after infection.

As shown in Table I and Fig. 1, acetone-washed cells of BCG share with salmonella endotoxin the ability to elicit protection against $M y c o$. fortuitum and to increase the rate of clearance of carbon particles. The following experiment shows that pretreatment with the BCG material also modifies the clearance response of mice following infection with Myco. fortuitum.

Thirty-five mice, 4 weeks old, received by the intraperitoneal route $100 \mu \mathrm{g}$. of acetoneextracted BCG cells. One week later all were challenged by intravenous injection of $0.05 \mathrm{ml}$. of a 6 day old tween-albumin culture of $M y c o$. fortuitum diluted to a final volume of $0.2 \mathrm{ml}$. Thirty-five untreated and uninfected animals served as controls. The phagocytic activity for carbon particles and the weight of the liver and spleen were determined for five animals of each group at various intervals of time after infection (Fig. 4).

As seen in Fig. 4, mice which had been pretreated with acetone-extracted BCG cells exhibited a marked increase in clearing activity for carbon particles as early as 16 hours after infection. The $K$ value began to fall only at the end of the experiment. The phagocytic index $\alpha$ also remained above normal for at 


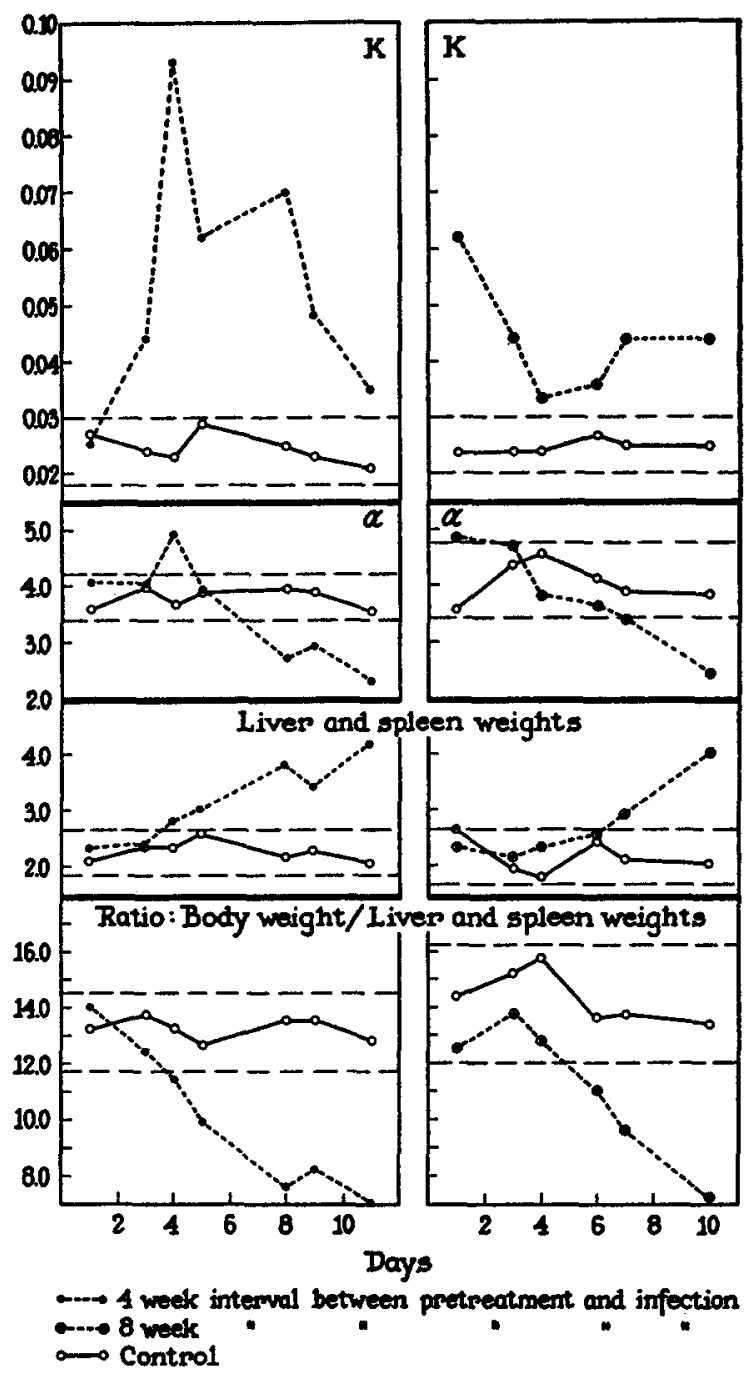

Fic. 3. Long term effect of infection on clearance rate of carbon particles in mice pre viously treated with pyrexal. Each point corresponds to the arithmetic means of five animals; the broken line indicates the standard deviation of the untreated controls.

Left: Animals treated intraperitoneally with $20 \mu \mathrm{g}$. of $S$. abortus equi endotoxin (pyrexal) suspended in $0.4 \mathrm{ml}$. of distilled water and challenged intravenously 4 weeks later.

Right: Animals treated intraperitoneally with $20 \mu \mathrm{g}$. of $S$. abortus equi endotoxin (pyrexal) suspended in $0.4 \mathrm{ml}$. of distilled water and challenged intravenously 8 weeks later.

Infective dose for both groups: $0.05 \mathrm{ml}$. of a 6 day old tween-albumin culture of $M y c o$. fortuitum, strain Penso, suspended in a final volume of $0.2 \mathrm{ml}$. of distilled water. 
least 5 days, then fell to a normal level as the weight of the liver and the spleen increased.

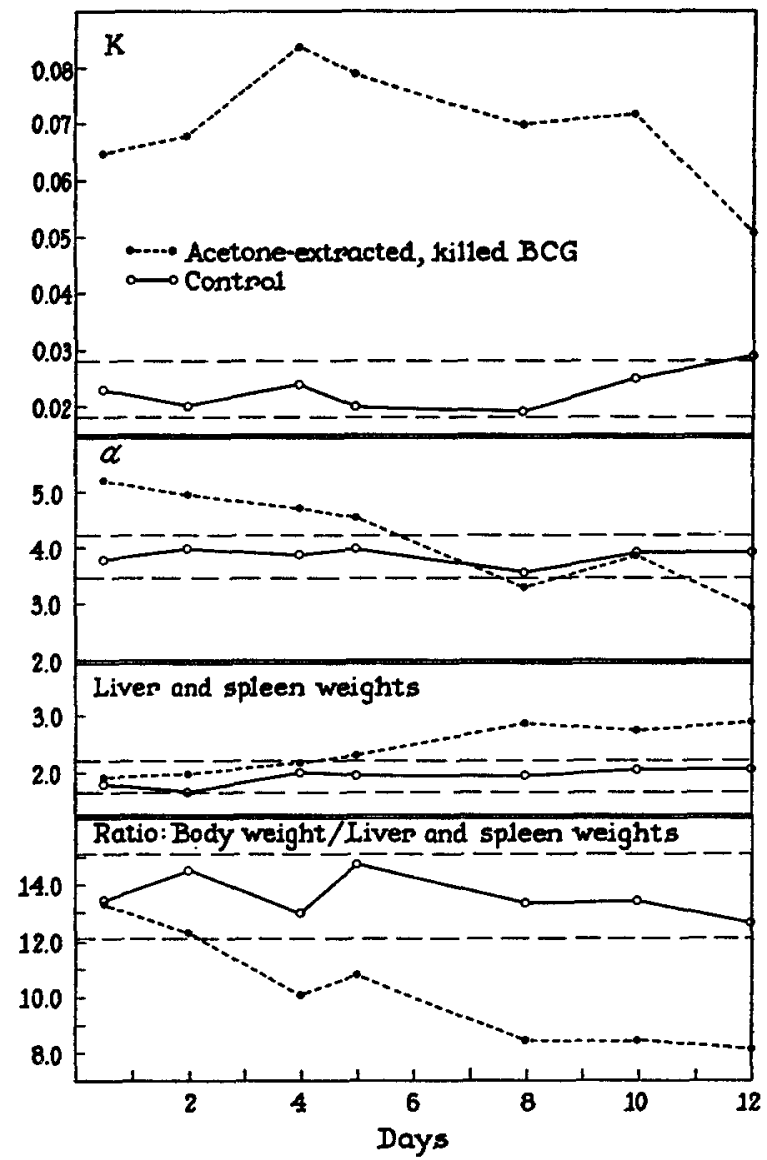

Fig. 4. Short term effect of infection on clearance rate of carbon particles in mice previously treated with acetone-extracted, killed BCG. Each point corresponds to the arithmetic means of five animals; the broken line indicates the standard deviation of the untreated controls. Animals treated intraperitoneally with $100 \mu \mathrm{g}$. acetone-extracted, killed BCG suspended in a final volume of $0.3 \mathrm{ml}$. of distilled water. Challenged intravenously 1 week later with $0.05 \mathrm{ml}$. of a 6 day old tween-albumin culture of $M y c o$. fortuitum, strain Penso, in a final volume of $0.2 \mathrm{ml}$. of distilled water.

\section{DISCUSSION}

One of the unexpected facts revealed by recent immunological investigations is the extent to which it is possible to alter in a non-specific manner the resistance of animals to experimental infection (1-5). The first striking results in this 
domain were obtained by treating animals with endotoxins of Gram-negative bacilli and by challenging them subsequently with other bacterial species belonging to this general group, but unrelated in immunological specificity. It was also found that treatment with endotoxins changes profoundly the properdin level of the blood, and that several of the Gram-negative pathogens are highly susceptible to the bactericidal effect of the properdin system (10). Because of these intriguing relationships, it has been assumed that the changes in resistance to infection observed as a result of treatment with endotoxins were the consequence of changes in properdin levels in the serum.

While it is possible, although not proved, that properdin plays some part in natural resistance to a few types of infection, it is certain that other factors are also involved. Thus it has been found that treatment with cellular components of mycobacteria can increase markedly the resistance of mice and guinea pigs to unrelated bacterial infections without modifying serum properdin levels. ${ }^{3}$ Moreover, treatment with endotoxins or with mycobacterial constituents can increase resistance to bacteria which are not susceptible to the properdin system, to staphylococci for example (3). It is of obvious interest, therefore, to inquire into the nature of the body mechanisms affected by endotoxins and by mycobacterial constituents in a manner that affects resistance to infection. One of these mechanisms is the phagocytic activity of the RES, as measured by the ability of animals to clear injected carbon particles from their blood stream (20).

As shown earlier, and confirmed in the present study, the resistance of mice to $M y c o$. fortuitum can be increased by treating the animals before infection with small doses of salmonella endotoxin $(20 \mu \mathrm{g}$.) or of cellular constituents of BCG $(100 \mu \mathrm{g}$.). The protection thus elicited lasts for several weeks. Treatment of mice with these small amounts of bacterial products also increases markedly their ability to clear carbon particles from the blood stream, but this change in phagocytic activity is of short duration. An increase in phagocytic activity also takes place shortly after the animals have been infected with $M y c o$. fortuitum and the rate of clearance of carbon particles in infected animals remains elevated until the infection becomes overwhelming. Experiments were designed to determine the interplay of these different factors and the influence of time upon them. It was found that in animals which had been previously treated with endotoxin or with the constituents of BCG cells, infection with $M y c o$. fortuitum produced an increase in clearance rate of carbon particles much more pronounced and more lasting than in untreated animals. Moreover, the difference in clearance rate between the two groups was still evident after the animals

\footnotetext{
${ }^{3}$ Measurements of properdin levels in mice treated with killed tubercle bacilli or with methanol extracts of them were carried out during 1956 by Dr. L. Pillemer who generously made the results available to us. The properdin levels were normal in mice tested 2 days and 2 weeks after injection of $1 \mathrm{mg}$. of mycobacterial constituents, at a time when the animals exhibited increased resistance to infection.
} 
had apparently returned to the normal state following treatment with endotoxin or BCG cells. Four weeks and even 8 weeks after receiving small amounts of salmonella endotoxin, mice responded to infection with $M y c o$. fortuitum by an accelerated and abnormally high ability to clear carbon particles from their blood stream.

Thus, administration of salmonella endotoxin or of BCG cells modifies profoundly and lastingly the response of mice to subsequent infection as well as their phagocytic activity. It is tempting to believe that the greater resistance of the treated animals is the consequence of enhanced phagocytic activity. In reality, however, there is no proof of causal relationship between these changes. Indeed, the fact that some of the pathogens used in the infection tests survive and multiply intracellularly in all types of cells so far tested, militates against the view that increase in phagocytic activity can account for increase in resistance to infection. Until further knowledge is available, it seems safer to assume that activation of the so called RES by salmonella endotoxin or by killed BCG cells is only one index of a complex of physiological changes, one or several of which - as yet unidentified-will modify the resistance of animals to living microbial agents or to their toxic products. ${ }^{4}$

\section{SUMMARY}

Administration of small amounts of salmonella endotoxin $(20 \mu \mathrm{g}$.) or of acetone-extracted BCG cells $(100 \mu \mathrm{g}$.) increases the resistance of mice to infection with $M y c o$. fortuitum as well as their ability to clear carbon particles from their blood stream. Whereas the increased resistance to infection persists for many weeks, the clearing power returns to a normal level within a few days.

When normal mice are infected with $M y c o$. fortuitum, there occurs during the first phase of the infectious process a rise in clearing power for carbon particles followed by a fall during the terminal phase of the disease. The rise occurs more rapidly and is more pronounced in animals previously treated with salmonella endotoxin or with killed BCG cells. This acceleration and intensification of the phagocytic response to infection can be detected even in animals which exhibit a normal phagocytic index when tested several weeks after administration of endotoxin or of $\mathrm{BCG}$.

Although increase in resistance to infection is correlated with activation of the so called reticulo-endothelial system, there is no evidence of any direct causal relationship between the two phenomena.

\footnotetext{
${ }^{4}$ Worthy of consideration in this regard is the well known fact that the endotoxins of Gram-negative bacilli and some unidentified cellular constituent of mycobacteria can act as adjuvants in the production of humoral antibodies or of delayed hypersensitiveness. Although it is well possible that the adjuvant activity plays a role in the increase of resistance to infection, this aspect of the problem will not be discussed here.
} 


\section{BIBLIOGRAPHY}

1. Rowley, D., Stimulation of natural immunity to $E$. coli infection, Lancet, 1955, 1, 232.

2. Landy, M., Increased resistance to infection developed rapidly after administration of bacterial lipopolysaccharides, Fed. Proc., 1956, 15, 598.

3. Dubos, R. J., and Schaedler, R. W., Reversible changes in the susceptibility of mice to bacterial infections. I. Changes brought about by injection of pertussis vaccine or of bacterial endotoxins, J.Exp. Med., 1956, 104, 53.

4. Weiss, D. W., and Dubos, R. J., Antituberculous immunity induced by methanol extracts from tubercle bacilli-its enhancement by adjuvants, J. Exp. Med., 1956, 103, 73.

5. Dubos, R. J., and Schaedler, R. W., Effects of cellular constituents of mycobacteria on the resistance of mice to heterologous infections. I. Protective effects, J. Exp. Med., 1957, 106, 703.

6. Westphal, O., and Liuderitz, O., Chemische Erforschung von Lipopolysacchariden gramnegativer Bakterien, Angew. Chem., 1954, 66, 407.

7. Howard, J., Rowley, D., and Wardlaw, A. C., Stimulation of nonspecific immunity by the lipid A component of bacterial lipopolysaccharide, Nature, 1957, 179, 314.

8. Westphal, O., personal communication.

9. Fritze, E., Doering, P., Manecke, H., and Schoen, R., Oberflächenveränderugen der Blutzellen durch pyrogene Reizstoffe, Schweiz. med. Woch., 1953, 83, 783.

10. Landy, M., and Pillemer, L., Increased resistance to infection and accompanying alterations in properdin levels following administration of bacterial lipopolysaccharides, J. Exp. Med., 1956, 104, 383.

11. Keiderling, W., Wöhler, F., and Westphal, O., Utber bakterielle Reizstoffe IV. Experimentelle Untersuchungen zur Differenzierung der therapeutischen Wirkungen von bakterieller Vakzine, reinem Polysaccharid Pyrogen und acetylierten Polysaccharid-Derivaten aus gramnegativen Bakterien, Arch. exp. Path. u. Pharmakol., 1953, 217, 293.

12. Elberg, S. S., Factors affecting resistance to infection, Ann. Rev. Microbiol., 1956, 10,6 .

13. Biozzi, G., Benacerraf, B., and Halpern, B. N., The effect of $S$.typhi and its endotoxin on the phagocytic activity of the RES in mice, Brit. J. Exp. Path., 1955, 36, 226.

14. Bennett, I. L., and Beeson, P. N., The properties and biologic effects of bacterial pyrogens, Medicine, 1950, 29, 365.

15. Burrows, W., Endotoxins, Ann. Rev. Microbiol., 1951, 5, 181.

16. Thomas, L., The physiological disturbances produced by endotoxins, Ann. Rev. Physiol., 1954, 16, 467.

17. Biozzi, G., Benacerraf, B., Grumbach, F., Halpern, B. N., Levaditi, J., and Rist, N., Etude de l'activité granulopexique due système SRE au cours de l'infection tuberculeuse expérimentale de la souris, Ann. Inst. Pasteur, 1954, 87, 291.

18. Biozzi, G., Halpern, B. N., Benacerraf, B., and Stiffel, C., Phagocytic activity of the RES in experimental infection. Physiology of the RES. A Symposium. Oxford. Blackwell Scientific Publications, 1957, 204. 
19. Benacerraf, B., and Sebestyen, M., The effect of bacterial endotoxins on the RES, Fed. Proc., 1957, 16, 860.

20. Benacerraf, B., Biozzi, G., Halpern, B. N., and Stiffel, C., Physiology of the RES. A Symposium, Oxford, Blackwell Scientific Publications, 1957, 52.

21. Halpern, B. N., Biozzi, G., Mene, G., and Benacerraf, B., Etude quantitative de l'activité granulopexique du système SRE par l'injection intraveineuse d'encre de Chine de particules de carbone de dimensions connues, Ann. Inst. Pasteur, 1951, 80, 582.

22. Halpern, B. N., Benacerraf, B., and Biozzi, G., Quantitative study of the granulopectic activity of the RES: A study of the kinetics of the granulopectic activity of the RES in relation to the dose of carbon injected. Relationship between the organs and their activity, Brit. J. Exp. Path., 1953, 34, 426.

23. Benacerraf, B., Biozzi, G., Cuendet, A., and Halpern, B. N., Influence of portal blood flow and of partial hepatectomy on the granulopectic activity of the RES, J. Physiol., 1955, 128, 1.

24. Hill, A. B., Principles of medical statistics, London, The Lancet, Ltd., 3rd edition, 1942. 